\title{
Rendering Auto-Antonyms in the Glorious Qur'an
}

\author{
Asmaa El-Zieny \\ Department of English Language \& Literature \\ Faculty of women for Science, Arts and Education \\ Ain Shams University \\ somaelzieny@yahoo.com
}

\begin{abstract}
This paper examines rendering auto-antonyms in The Glorious Qur'an in three selected translations of the meanings of The Glorious Qur'an. The term auto-antonyms has been coined to describe a linguistic phenomenon of the Arabic language by which a single word can carry two antonyms. The examples will be selected from The Meaning of the Glorious Qur'an (1930) by Muhammad Marmaduke Pickthall, Interpretation of the Meanings of the Noble Qur'an (1999) by Muhammad Mohsen Khan and Muhammad Taqi al-Din al-Hilali, and Towards Understanding the Ever-Glorious Qur'an by Muhammad Mahmoud Ghali (2003). The examination is achieved by applying Newmark's notion of semantic versus communicative translation and compensation strategies set forth by Dickens, Hervey, and Higgins (2002).
\end{abstract}

Keywords: Auto-antonyms, Qur'an, Translation, semantic, communicative, compensation strategies

\section{Introduction}

The current paper sheds light on the translation of auto-antonyms in The Glorious Qur'an. The term auto-antonyms describes a unique phenomenon of the Arabic language when a single word carries two antonyms. To effectively carry out this paper, three translations were chosen. The three translations are as follows: Towards Understanding the Ever-Glorious Qur'an (2003) by Muhammad Mahmoud Ghali, Interpretation of the Meanings of the Noble Qur'an (1999) by Muhammad Muhsin Khan and Muhammad Taqi al-Din al-Hilali, and The Meaning of the Glorious Qur'an (1930) by Muhammad Marmaduke Pickthall. The Glorious Qur'an has undoubtedly provided a level of linguistic excellence unparalleled in the history of the Arabic language as Muslim and nonMuslim linguists admitted. Arabic is a unique, expressive, and highly complex. It is also very rich phonologically, morphologically, semantically, and syntactically. Its unique features and characteristics include diacritical markers, parsing signs, dual forms of nouns and verbs, and a multitude of inter-clausal connectors. 
Moreover, the language of The Glorious Qur'an is replete with examples that reveal its eloquence and high degree of specification. One of the most evident examples of this can be elucidated by The Glorious Qur'an's selection of terms for implicit linguistic and rhetorical purposes. As a result of the nature of the Arabic language, linguists have always been interested in translating the meanings of The Glorious Qur'an. According to Abdul-Raof, translating The Glorious Qur'an is "a major human contribution in cross-cultural Interfertilization"(abdulRaof2001:1)

Raof (2001:37) asserted that the miraculous nature of The Glorious Qur'an is undoubtedly "a linguistic miracle... beyond human faculty to produce a single verse that could match it." The three translators of the works under study admitted that there are problems directly associated with Qur'an translation due to its unique characteristics and exquisite style. The current work tackles the linguistic problem of translating The Glorious Qur'an This paper can assist translators in selecting more accurate equivalent for auto-antonyms and produce more accurate translations of The Glorious Qur'an

\section{Objectives}

This paper is designed to add to the field of Qur'an translation. It aims at conducting semantic comparisons of auto-antonym word selections in three different English translations of Qur'an. In other words, the focus of the present paper is to achieve the following objectives:

- Clarify the nature of auto-antonyms in The Glorious Qur'an that a translator may fail to capture if he/ she is not acquainted with them.

- Diagnose the problems that face translators of The Glorious Qur'an as they produce word selections for auto-antonyms.

- Probe into the compensation strategies adopted by the translators of the three selected works.

\section{Problem}

Notably, there is an ever-growing demand for Qur'an translations, as a result of the increase number of the new Muslims. According to pew research center, Islam has become the fastest growing religion in the past few years. This increase necessitates the need to a translations that delivers the true message of Islam to these new Muslims. Needless to say, translations of the Glorious Qur'an are numerous and varied. There is an urgent need to a continuous study of the previous translations of The Glorious Qur'an and to produce new ones in the future. 
Auto-antonyms are words that mean a thing and its opposite so naturally they pose a problem in translation. When translators encounter auto-antonyms they may have a serious dilemma knowing which of the two meanings is intended. Because the two meanings are opposites. The inaccurate translation of any autoantonym would distort the meaning of the verse.

Therefore, the translator is forced to choose only one meaning and leave the other. As a result, translators cannot successfully ascertain the accurate meaning of the verse without being acquainted with what the exegetes have said about the two meanings. The linguistic and cultural background of the translator becomes crucial at this point and the strategies he/she employs has the ability to add richness to his/her translation.

Peter Newmark, British translation theorist, divides translation into two types: communicative and semantic translation. He discusses various methods of translation to ascertain what he refers to as equivalence. He also develops new practices and approaches to translation. According to his communicative translation theory, translation is considered to be a kind of communication process, in which translators should always convert the source language (SL) into the target language (TL) as much as possible (Newmark, 1981).

\section{Questions}

This paper seeks to answer the following questions:

1. What are auto-antonyms? What is the nature of their use in The Glorious Qur'an?

2. Which compensation strategies the translators use to alleviate meaning loss?

3. What role does the linguistic and cultural background of the translator play in rendering translations?

\section{Hypotheses}

The paper attempts to investigate the following hypothesis:

6. As a native speaker of Arabic, Ghali is more capable of conveying the accurate meaning of auto-antonyms .

\section{Auto-Antonyms}

Auto-Antonym is a word that has one form and two opposite meanings. In Arabic, the word is called 


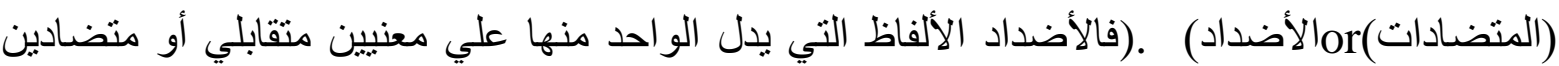
كالجلل للعظيم و اليسير

According to Nassar (2003: $\vee$ ), scholars of the Arabic language documented the history of the Arabic language during the same period of composing the Arabic dictionaries. They mainly aimed at preserving their language. Auto-antonyms were documented during the third phase of the development of the Arabic sciences Scholars of this era, such as al-Așma't̄, al-Sijistānī, Ibn al-Sakīt, Quțrub, Abū al-Tayyib al-Lughawī, Ibn Dahān, al-Šaghānī, and Ibn al-'Anbarī composed books on auto-antonyms. Such books were edited and republished by Orientalists during the 19th and 20th centuries. A number of these scholars considered autoantonyms. a result of people's unconsciousness, Kamel in his introduction to Jurji Zaydan's book, The Arabic Language and Linguistic Philosophy (1987).

Reviewing the history of the Arabic language proves that the ancient Arabs are eager for differentiating the various types of words (Nassar, 2003). Autoantonyms is a model of the variation of style in the Arabic Language and _an evidence of the flexibility and the easiness of moving from the negative to the positive. Moreover, phenomenon of auto-antonyms is an evidence of the Arabs ability in oratory, thus, Scholars exerted great effort to study it.

\section{8. -Semantic and Communicative Translation.}

Following the footprints of the famous linguists Newmark(1981) wrote many articles and theoretical works on translation. He deviates from Nida's receptor-oriented thought. Newmark sees that the success of equivalent effect as "illusory" and that "the conflict of loyalties, the gap between emphasis on source and target language will always remain as the overriding problem in translation theory and practice" (Munday 2016:60).

Semantic translation is a mode of text transfer, which involves using (the bare syntactic and semantic constraints of the TL to reproduce the precise contextual meaning of the author, Newmark, 1981:2While communicative translation is a mode of text transfer, which seeks (to produce the same effect on the TL readers as was produced by the original, Newmark, 1981). The main focus is to create an effect similar to that of the Source text.

Newmark distinguishes between the communicative versus semantic translation and the Word-for-word (or formal or literal) translation which he highly praised and recommended as a procedure which works well most of the time and constitutes the bulk of what translators do. In communicative as in semantic translation, if equivalent effect is secured, the literal word-for-word 
translation is not only the best, it is the only valid method of translation (Newmark, 1981).

\section{Compensation Strategies}

Although the losses in translation are undesirable, they are also inevitable in many cases (Dickens, Hervey and Higgins (2002).

Dickens, Hervey and Higgins (2002) also saw that when the translator finds great difficulty translating something the does something that goes with the original text. While Baker defines Compensation strategy as "a technique which involves making up for the loss of a source text effect by recreating a similar effect in the target text through means that are specific to the target language and/or text" (Baker, 2011:26).

Compensation strategies function as an indemnity for softening what is deemed lost. We can distinguish several forms of compensation, which Hervey and Higgins(2002) classify compensation strategies into four main types. First, is compensation in kind, second is compensation in place, third is compensation by merging and fourth is compensation by splitting (Hervey and Higgins, 2002).These Compensation strategy enables the translator to avoid an overall weakening of the ST, which emerges due to the inevitable translation loss. Moreover, these compensation strategies may be applied to any kind of loss including linguistic or stylistic effects (Baker, 2011).

10-Analysis

\begin{tabular}{|c|c|c|c|}
\hline الأية & المتضادان المعنيان & الكلمة & \\
\hline \multirow[t]{2}{*}{ طad10 } & كتم & \multirow[t]{2}{*}{ اخفي } & \multirow[t]{2}{*}{.1} \\
\hline & ظهر & & \\
\hline \multirow[t]{2}{*}{ يونس ؟0 } & أظهر & \multirow[t]{2}{*}{ أسر } & \multirow[t]{2}{*}{. } \\
\hline & أخفي & & \\
\hline \multirow{3}{*}{ يوسف Y } & الضعف بلغ & \multirow[t]{3}{*}{ أنثده } & \multirow[t]{3}{*}{.$^{r}$} \\
\hline & 11 & & \\
\hline & القوة بلغ & & \\
\hline النحل.r & الو احد & \multirow[t]{2}{*}{ أمة } & \multirow[t]{2}{*}{.$\xi$} \\
\hline البقرة YIY & الجماعة & & \\
\hline \multirow[t]{2}{*}{ الأنعامع 9} & الفراق & \multirow[t]{2}{*}{ بين } & \multirow[t]{2}{*}{.0} \\
\hline & الوصل & & \\
\hline
\end{tabular}




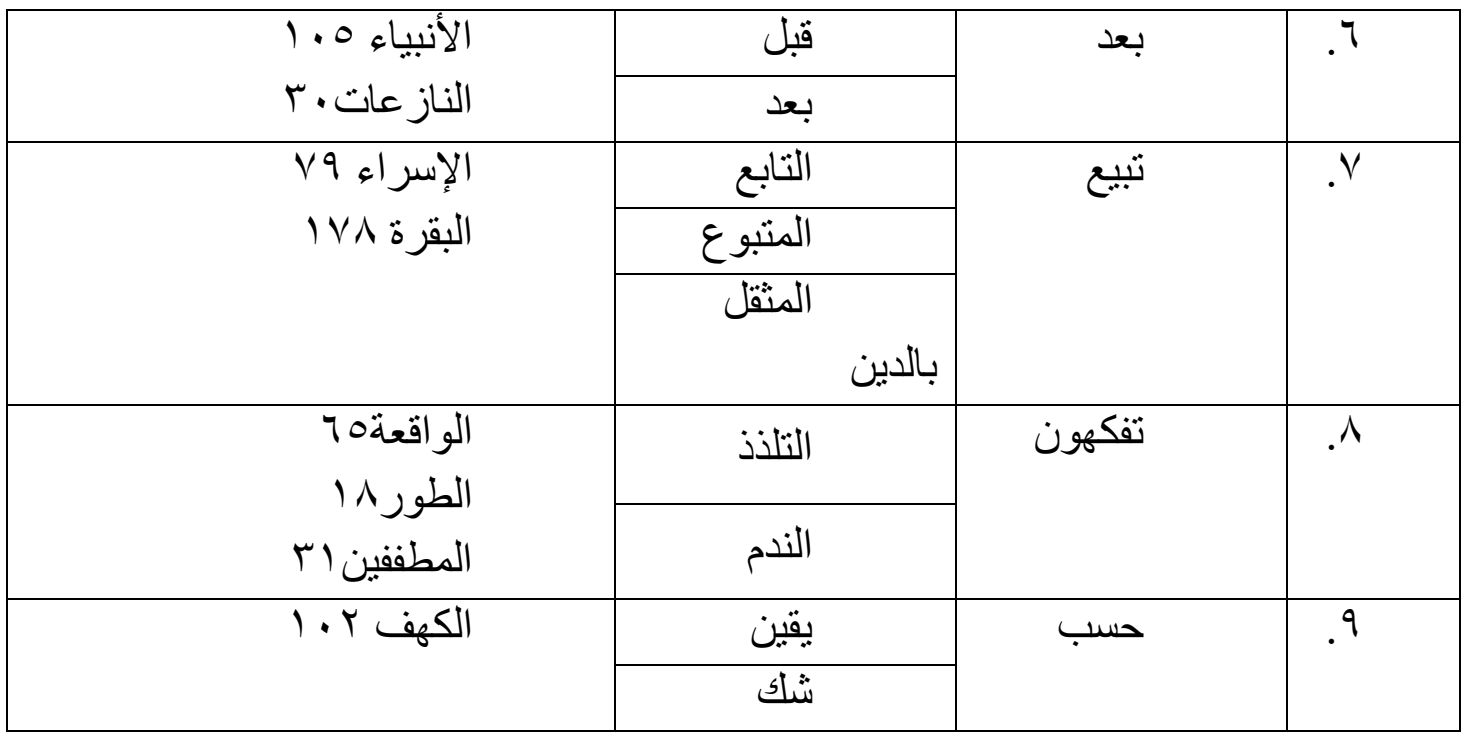

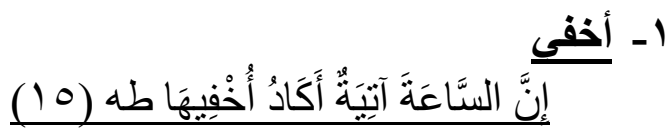

\section{Ghali:}

.Surely the Hour is coming up-I would almost conceal it-

\section{Hilali \& Khan :}

Verily, the Hour is coming and My Will is to keep it hidden

\section{Pickthall :}

Lo! the Hour is surely coming. But I will to keep it hidden,

\begin{tabular}{|c|c|c|l|c|}
\hline The word & Ghali & Hilali\&Khan & Pickthall & $\begin{array}{l}\text { The two } \\
\text { opposite } \\
\text { meanings }\end{array}$ \\
\hline أخفيها & $\begin{array}{c}\text { I would almost } \\
\text { conceal it }\end{array}$ & $\begin{array}{c}\text { To keep it } \\
\text { hidden }\end{array}$ & $\begin{array}{c}\text {.I will to keep } \\
\text { it hidden. }\end{array}$ & \begin{tabular}{c} 
أظهر \\
\hline
\end{tabular} \\
\hline
\end{tabular}

The auto-antonym أخفيها is translated as (keep hidden) by both Hilali \& Khan and by Pickthall and as (conceal). It is clear that the three translators chose the meaning of hide for the auto-antonym and neglected the other meaning as (show) although it is stated by Al Baghwi in his exegesis that the word means both show and hide and this is of the ejaaz of the Qur'anic word. So, this other meaning of the word is functional in the verse and is lost because the T L lacks such a word that bears the two opposite meanings. By using the word almost Ghali reverted to parallel compensation strategy. Hilali and Pickthall used the compensation in kind strategy of translation by explanation to give more explanation of the meaning. 


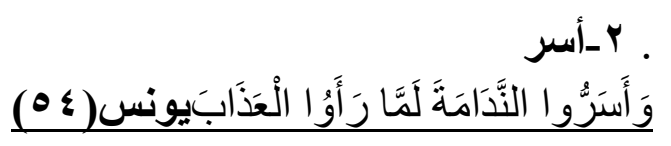

\section{Ghali:}

they will keep secret (their) remorse as soon as they see the torment,

\section{Hilali\&Khan:}

And they would feel in their heart regret

\section{Pickthall:}

and they will feel remorse within them, when they see the doom.

\begin{tabular}{|l|l|l|l|l|}
\hline The word & Ghali & Hilali\&Khan & Pickthall & $\begin{array}{l}\text { two } \\
\text { meanings }\end{array}$ \\
\hline أسرة & will keep secret & $\begin{array}{l}\text { feel in their heart } \\
\text { regret }\end{array}$ & willfeel remorse. \\
\hline
\end{tabular}

The auto-antonym أسر is rendered by Ghali as (keep secret). It is rendered by Hilali\&Khan as (feel in heart), while it is rendered by Pickthall as (feel) only. Ghali's translation is in accordance with what Al Mttourdy in his exegesis said. The other functional meaning is here lost. Hilali's choice (feel in heart) is far away from the two opposite meanings. Also Pickthall choice, ( feel) is not one of the two specified meanings. The translation by addition that Hilali\&Khan did is somehow explanatory one that added more meaning to the translation to compensate some of the lost meaning.

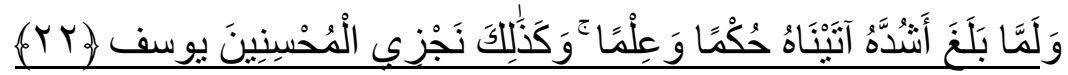

\section{Ghali:}

And when he reached full age, We brought him judgment and knowledge; and thus We recompense the fair-doers.

\section{Hilali\&Khan:}

And when he [Yusuf (Joseph)] attained his full manhood, We gave him wisdom and knowledge (the Prophethood), thus We reward

\section{Pickthall:}

22. And when he reached his prime We gave him wisdom and knowledge. Thus We reward the good.

\begin{tabular}{|l|l|l|l|l|}
\hline $\begin{array}{l}\text { The } \\
\text { word }\end{array}$ & Ghali & Hilali\&Khan & Pickthall & meanings \\
\hline
\end{tabular}




\begin{tabular}{|c|c|c|c|c|}
\hline أشده & $\begin{array}{l}\text { full } \\
\text { age }\end{array}$ & his prime & his full manhood. & الضعف بلغ الثقة بلغ ، 1 أل \\
\hline
\end{tabular}

Auto-antonym أنثده is rendered by Ghali as (full age). Which means the legal age which may mean maturity or adolescence. Hilali\&Khan rendered it as (prime) and in_Cambridge Advanced Learners Dictionary it means the period of life when you are most active. This word is nearer to 18 years old as youth are more active. Pickthall rendered it as (full manhood). This is mostly means to reach 40 both Hilali\&Khan and Pickthall used an explanatory translation of the meaning of the word. They communicated the meaning of the word avoiding the semantic translation of the word. In this example the two antonym meanings are given.

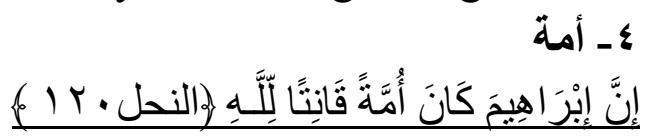

\section{Ghali :}

.Surely, Ibrahîm (Abraham) was a nation, (i.e., a leader, Imam)

\section{Hilali\&Khan:}

Verily Ibrahim (Abraham was an Ummah (a leader having all the good righteous qualities), or a nation.

\section{Pickthall:}

.Lo! Abraham was a nation obedient to Allah, by nature upright, and he

\begin{tabular}{|c|c|c|c|c|}
\hline $\begin{array}{l}\text { The } \\
\text { word }\end{array}$ & Ghali & Hilali \& Khan & Pickthall & $\begin{array}{l}\text { The two } \\
\text { meanings }\end{array}$ \\
\hline أمة & $\begin{array}{l}\text { A nation } \\
\text { (i.e., a leader, } \\
\text { Imam) }\end{array}$ & $\begin{array}{l}\text { was an Ummah (a } \\
\text { leader having all the } \\
\text { good righteous } \\
\text { qualities), or a nation. }\end{array}$ & was a nation & الجماعة \\
\hline
\end{tabular}

The auto-antonym أمة is rendered by Ghali and Picktall as nation, while Hilali\&Khan and Pickthall transliterated the Arabic word as ummah. Moreover, Hilali\&Khan followed the transliteration by a parenthetical long phrase to give more explanation of the word then he gives another alternative, the translation of 
the word to (a nation). Although transliteration exposes the target reader to the Arabic word, it may leave him perplexed as he/she has no idea about the S L.

The explanation thatGhali used no compensation strategy the. while Hilali \&Khan used the compensation kind by transliterating the auto-antonym and Picktall also did not use any compensation strategies.

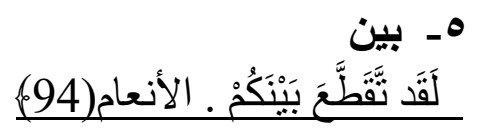

\section{Ghali:}

Indeed (the bonds) between you are already cut off,

\section{Hilali\&Khan:}

Now all relations between you and them have been cut off

\section{Pickthall:}

Now is the bond between you severed,

\begin{tabular}{|l|l|l|l|l|}
\hline The word & Ghali & Hilali\&Khan & Pickthall & $\begin{array}{l}\text { The two } \\
\text { meanings }\end{array}$ \\
\hline بين الفراق \\
الوصل
\end{tabular}

The auto-antonym is rendered by Ghali and Pickthall as (bond) and by Hilali\&Khan as (all relations). Both words bond and relation are close in meaning to الوصل (اق) The other meaning of the auto-antonym word given although it is functional as Al Thaalby in his exegstated that it has the two opposite meaning .here are no compensation strategies used to indicate the two opposite meaning of the word.

\section{Ghali:}

$$
\begin{aligned}
& \text { 7-بعد }
\end{aligned}
$$

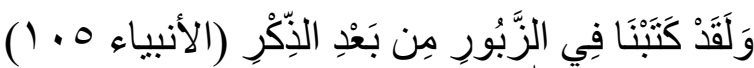

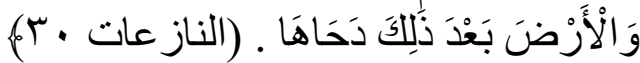

. And indeed We have already written in the Scripture, (The Zabûr $=$ the Psalms) even after the Remembrance,

. And the earth, after that He flattened it (for life)

\section{Hilali\&Khan:}

And indeed we have written in AzZAbur (i.e all reveled Holy Books-the Taurat (the Injeel Gospel, the Psalms, The Glorious Qur'an after (we have already written in) Al-Lauh Al-Mahfuz (the Book that is in the Heaven with Allah )

-And after that He spread the earth 


\section{Pickthall}

And verity We have written in the Scripture, after the Reminder

. And after that He spread the earth.

\begin{tabular}{|l|l|l|l|l|}
\hline The auto-antonym word & Ghali & Hilali\&Khan & Pickthall & $\begin{array}{l}\text { The two } \\
\text { meanings }\end{array}$ \\
\hline بعبل قبل & after & after & .after & بع \\
\hline
\end{tabular}

Here the auto-antonym بعد in the six different positions (of the two positions) is rendered by the three translators as after. No one of the three translators gave the opposite meaning of the word, although it is one of the two opinions that the exegeses mentioned in the verse talking about the creation of land al Qurtoby assured that this auto-antonym has the two opposite meanings. The not mentioned one is here lost in translation and is not alleviated by any compensation strategy. The auto-antonym word is rendered by the three translators as (after) even in the three following models.

$$
\begin{aligned}
& \text { V- تبيع }
\end{aligned}
$$

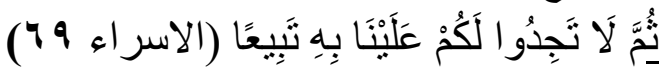

\section{Ghali:}

Thereafter you will find no attending followers for you against Us.

\section{Hilali\&Khan:}

then you will not find any avenger therein against Us?

\section{Pickthall:}

...then ye will not find therein that ye have any avenger against Us

\begin{tabular}{|l|l|l|l|l|}
\hline $\begin{array}{l}\text { The auto- } \\
\text { antonym } \\
\text { word }\end{array}$ & Ghali & Hilali\&Khan & Pickthall & $\begin{array}{l}\text { The two } \\
\text { opposite } \\
\text { meanings }\end{array}$ \\
\hline تبيع التابع & $\begin{array}{l}\text { No attending } \\
\text { followers }\end{array}$ & avenger & any avenger \\
\hline
\end{tabular}

The Auto-antonym تنيع is rendered by Ghali as (attending follower) which is a rather longer that means التابع. While both Hilali\&Khan and Pickthall rendered it as (avenger). The choice of the three translators, despite their different choice of word, _meaning تابع meaning. In Al moagem AlWaseet, التبيع) التَّابع والمطالب) بالثأر and in El Nasafy, mentioned that the auto-antonym in this verse means the two opposite meanings. The target reader inevitably lost one of the two functional meanings of the Auto-antonym word in this verse. 


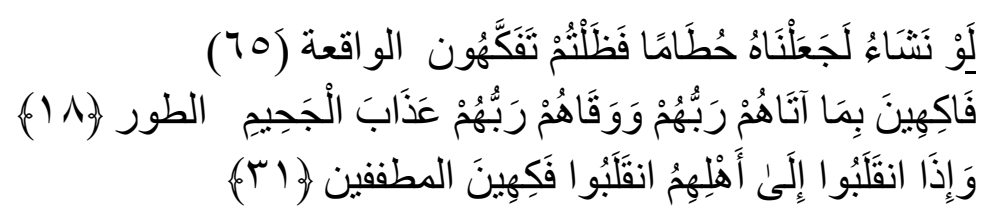

Ghali

If We had (so) decided We would indeed have made it crushed to pieces; then you would linger on (bitterly) exclaiming,

Jesting with what their Lord has brought them, and their Lord will protect them from the torment of Hell-Fire.

31. And when they turned over (to their families), they turned over jesting,

\section{Hilali\&Khan}

Were it our will we could crumble it to dry pieces and you would be regretgul (or left in wonderment) (Tafsir Ibn Kathir)

Enjoying in that which their Lord has bestowed on them and (the fact that)

And when they returned to their own people, they would return jesting

\section{Pickthall}

. If We willed, We verily could make it chaff, then would ye cease not to exclaim:

-.Happy because of what thee Lord hath given them, and (because) their Lord hath warded off from them the tormentof hell fire

- And when they returned to their own folk, they returned jetting;

\begin{tabular}{|c|c|c|c|c|}
\hline The word & Ghali & Hilali\&Khan & Pickthall & $\begin{array}{l}\text { The two } \\
\text { meanings }\end{array}$ \\
\hline تفكهون & $\begin{array}{l}\text { (bitterly) } \\
\text { exclaiming }\end{array}$ & $\begin{array}{lr}\text { regretgul (or } \\
\text { left } \\
\text { wonderment) }\end{array}$ & $\begin{array}{l}\text { would ye cease } \\
\text { not to exclaim: }\end{array}$ & التلتنز \\
\hline & Jesting & Enjoying & Happy & \\
\hline & jesting, & Jesting & jetting & \\
\hline
\end{tabular}

In the first example تفكهون, Ghali renderes it as (bitterly) exclaiming and in the following two models, he translates it as jesting. Hilali \& Khan translates into glad and the two following as enjoying and jesting. Pickthall uses a highly formal English form by using (would ye cease not to exclaim) and translates it into cease not to exclam, and inthe two following examples into enjoy and jetting respectively. The three translators have chosen the meaning of التلأذ. The other meaning الندم is, thus, lost. To alleviate this loss, Pickthall has opted for compensation strategy translation by explanation. 


\section{Ghali:}

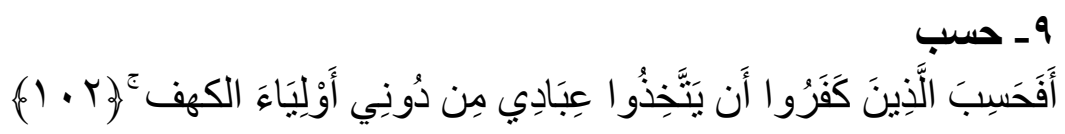

102. So, do the ones who have disbelieved reckon that they may take to themselves My bondmen as patrons, apart from Me?

\section{Hilali\&Khan:}

Do then those who disbelieve think that they can take My slaves [i.e., the angels, Allah's Messengers, 'Iesa (Jesus), son of Maryam (Mary), etc.] as Auliya' (lords, gods, protectors, etc.) besides Me?

\section{Pickthall:}

102. So, do the ones who have disbelieved reckon that they may take to themselves My bondmen as patrons, apart from Me?

\begin{tabular}{|l|l|l|l|l|}
\hline The word & Ghali & Hilali\&Khan & Pickthall & The two meanings \\
\hline حسب شئن & reckon & think & Reckon & \\
\hline
\end{tabular}

The auto-antonym حسب is rendered by Ghali and Pickthall as (reckon) which in Cambridge Advanced Learners Dictionary means to consider or have opinion. Hilali \& Khan rendered it as think. The two choices means the يقين, not the الثنك. Al thaalby, in his exegesis, states that it means حسبهم وكفايتهم or that is enough for them and this meaning is, also, not the one understood from the given translation. By using reckon Ghali has communicated the meaning of اليقين and no compensation strategy is used to compensate the lost meaning.

\section{Conclusion}

Analysis of the translation of auto-antonyms in the previous examples showed that each of the three translators made a genuine effort to make his translation as accurate as possible. They have tried as much as the TL allowed to make this category of words, the auto-antonyms, clear to the target reader as much as possible. It is obvious from each translators usage of structure and whether highly formal or just formal, that each translator is much affected by his own linguistic and cultural background. In different positions, the words are explained appropriately. And in some positions more explanation is needed for the auto-antonym.

To the researcher Ghali's language is the easiest to understand and the clearest to the readers of average religious knowledgethis is seen through the 
simple common words that he uses . Pickthall's English is more fine and elegant. On the other hand, Hilali depended more on addition to the text to explain it more.

The three translators agreed on the choice of some words such as the autoantonym بعد. The three of them rendered it as after and even in the different verses.

In auto-antonym أخفيها is both Hilali \& Khan and Pickthall chose the same translation . the three translators chose the meaning of hide. The other meaning as (show) is lost although it is functional Ghali reverted to the compensation strategy of translation by explanation

In rendering the (أمة) two translators reverted to transliteration which that unlike translation only gives you an idea of how the word is pronounced, by putting it in a familiar alphabet. It changes the letters from the word's original alphabet to similar-sounding letters in a different one.in transliteration meaning is not given to the target reader.

Auto-antonym Ghali and Pickthall chose the same translation and Hilali\&Khan translated it differently

In general, rendering Auto-antonyms in the Glorious Qur'an is a hard task that requires the translator to be aware of this category of words. In addition, the translator should try to make Auto-antonyms clear to the target reader using the suitable compensation strategy as offered by Dickens, Hervey, and Higgins.

\section{Bibliography:}

Baker, James R. William Golding: A Critical Study. New York: St. Martin's Press, (1965).

Dickins, J., Hervey S., \& Higgins, I. (2002). Thinking Arabic Translation: A Course in Translation Method: Arabic to English. London and New York: Roultege.

Ghali, M. (2008). Towards understanding the ever-glorious Qur'an (5th ed Cairo: DaraAn-Nashr Liljami 'at.

Kamali M. H. (2010). Rendering the terms of Fiqh(jurisprudence)into English :a comparative semanticstudy (Unpublished master's thesis). Cairo university.

Khan, M. \& Al-Hilali, M. (1996). Interpretation of the Meanings of the Noble Qur'an. Saudi Arabia

Kidawi, Abdur Rahim. "Translating the Untranslatable: A Survey of English Translations of the Qur'ân."retrievedfrom http://www.ilmgate.org/tag/Qur'anic-translation/ Original work published 
in The Muslim World Book Review, Vol. 7, No. 4, Summer 1987) "English translations of the Holy Qur'ân: An AnnotatedBibliography." p://www.Qur'an.org.uk/articles/ieb1stannotated.htm. (June 11, 2006). King Fahd Complex for the Printing of the Holy Qur'ân. "Translation of the Holy Qur'ân: Standards and Procedures." http://www.Divineislam.com/Articles/Qur'an/translation-pocedures.htm. (March 20, 2005).

Levý, J., \& Corness, P. (2011). The art of translation (Z. Jettmarová, Ed.). Benjamin's Translation Library.

Munday, J. (2016). Introducing translation studies theories and applications. London: Routledge, Taylor \& Francis Group.

Nida, Eugene A(1964)Toward a science of translating. Lieden:E.J Brill. House. J(2018) TRANSLATIONTHE BASICS(1est.ed )London Routledge Newmark Approaches to Translation Nord, C. (1997). Translating as a purposeful activity: Functionalist approaches explained. Manchester, UK: St. Jerome Pub.

House. J (2018) Translationthe Basics(lest.ed) London Routledge.

Newmark, P. (1981). Approaches to Translation. Oxford: Pergamon Press.

Nord, C. (1997). Translating as a purposeful activity: Functionalist approaches explained. Manchester, UK: St. Jerome Pub

Pickthall, M. (1953). The meaning of the glorious Koran. New York: New American Library. Cambridge. Pym, A. (2014). Exploring translation theories. Abingdon: Routledge.

Raof, H. (2001). Qur'an translation: Discourse, texture and exegesis. Richmond: Curzon.

Tawfik, K. M. (2011). Translating Problematic Words in the Glorious Qur'an: A Study of Three Translations.

Tawfik, k. M (2003). A Study of the Translation of Figurative Language in the Glorious Qur'an with Reference to Arberry, Dawood, Ghali and Yusuf Ali. Unpublished PHD. Thesis: Cairo University.

Yule, G. (2010). The study of language (4th ed.). Cambridge, UK: Cambridge University Press.

\section{Websites:}

http://Qur'ancomplex.gov.sa/Display.asp?section=8\&l=arb\&f=wrong trn3003\& $\underline{\operatorname{trans}=3}$ 
Lipka, M. (2017, February 27). Muslims and Islam: Key findings in the U.S. and around the world. Retrieved March 26, 2017, from http://www.pewresearch.org/fact-tank/2017/02/27/muslims-and-islam-keyfindings-in-the-u-s-and-around-the-world/ Muhammad Marmaduke Pickthall: A Servant of Islam https://www.meforum.org/717/assessing-english-translations-of-the-Qur'an https://dar-us-salam.com/authors/muhsin-khan.htm http://www.ilaam.net/Opinions/Pickthall.html

\section{Dictionaries:}

Dictionaries Online. Online at: http://dictionary.cambridge.org

Merriam-Webster's Online Dictionary. http://www.merriam-webster.com. > Oxford Advanced learners Dictionary. [Online at: $<$ http://oxforddictionaries.com

\section{Arabic References:}

The Glorious Qur'an

\section{Dictionaries}

Al Mogaam Alwasset

Al Mogaam AWjeet

Mogam El Aeen

Modern standard Arabic Dictionary

Ibn Manzoor Abu el Fadl Gamaal el Deen Muhammad bn Makram (The 1 Tongue of Arabs-Lysan El Arab)

\section{Books:}

Al Baghawy (The Remarks of Revelation in the Qur'an Exegesis) Maleem ELTanzeel Fi Tafseer ELQur'an) Ehyaaa Eltorath.

Al Dossary Muhammad bn Farhan Al Hawamlah (the Auto-antonyms in the Glorious Qur'an according to the Exegetists A theoretical

Al Qurtoby ( The collection of Qur'an Rulings Al Gama Le Ahkam El Qur'an Beirut Dar El Fikhr for printing and Publishing.

$\mathrm{Al}$ thalbi (Explanation and Elaboration -AlKashf Wa Al bayan LI Tafseer Al Qur'an)

Al Nasafi Exegesis ( the Exegesis of AlNasafi)

Gawaad A Mohammad El Mohs (Beauty in the Glorious Qur'an Concepts and fields) electronic version obtained from:

\section{https://archive.org/details/algmal fy Al Qur'an}

Hakeem A El Abd (beauty in the Glorious Qur'an commentaries and Frame Works Terminologies and modifications). Al Jamal FE Al Qur'an El 
Kareem Madakhel wa Otor- Mafaheem wa tasrofat fi Dawa

Nosoos Taselia men Al Ayat wa Al Ahadeeth) center of Languages and the Art Academy (2005)

Ibn Al Anbari (explaining the Stops and continuing of recitation -Edah Al Wasl Wa Al Wqf) first ed

Kareem A al yaffi (1996) ( Art studies in the Arabic Literature ) Lebanon

Beirut Nashron

Mujahid Exegesis (the Exegesis of Mujaheed)

Murad Kamel (Ilin the introduction of the linguistis philosophy and the Arabic words for Gorgi Zidan) Beirut nd. ed. 1982.

Nassar Hussien(2003) (linguistic Phenomena: Introduction to Addad) 1est ed al thqafa al dennyia publisher, Cairo, Egypt.

Omar AMukhtar ( Semantics) Alam El Kotob for printing and Publishing, cairo,Egypt

Salma Hassan Ahmad Al Badawy(The Auto-antonyms in the Glorious Qur'an ) thesis Research AL Qartom University 2006.

Tawwab A Ramadan(1999.) (Chapters in The Jurisprudence of the Arabic Language ) 6th ed, Cairo,Egypt

and Applied Study) thesis Study in the Qur'an and its Sciences Faculty of Osol El Deen Imam Muhammad bn Sood Islamic University, 1439- 1429H.

Lameen Latrish Muhammad (The Auto-Antonyms and its French Translation in Ibi Bakr Hamza ) thesis Sstudy Faculty of Arts and languages Constantine2008.

Hussien Muhammad (The Auto-Antonyms in Language) An Article in the Lysan Arbi Magazine Morocco $8^{\text {th }}$ ed 1971. Obtained from:

\section{http://search.mandumah.com/Record/179820}

Al Maa took Muhammad (Linguistic Phenomena) Lebanon Library Anani Muhmmad ( The Modern Translation Theory) AL Alamia for Publishing 2003.

\section{Articles:}

Al Bahra Nasr el Deen ( The Auto-Antonyms in the Arabic Language) an Arbitrated article in the Arabic Heritage Syria 20oo. Obtained from:

http://search.mandumah.com/Record/187449

Al Khateeb abdel Rahman( The Exerted Efforts for translating the Meanings of the Glorious Qur'an into English) the first scientific Conference for the researchers in the field of Qur'an and its Sciences and the Ummmah effort for 
serving the Qur'an, the Organization for the Scientific studies MUbdeea Rabat Morooco. Ontained from:

https://search.mandumah.com/Record/469322

\section{تزجمة الألفاظ المتضادة فى القرآن الكريم}

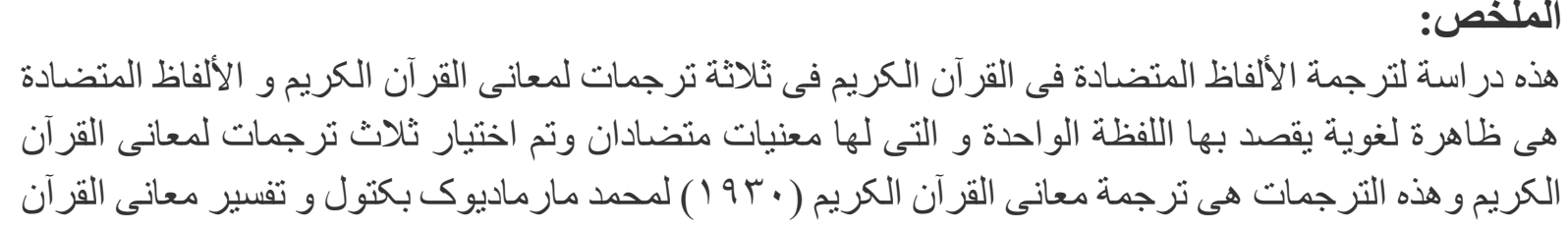

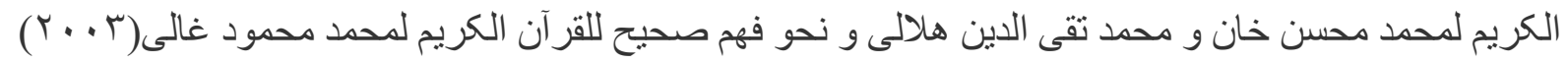

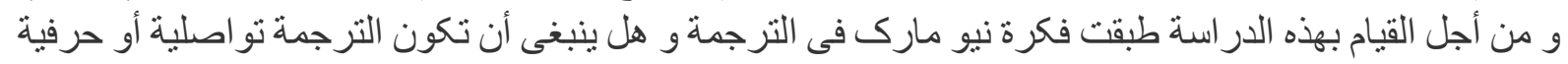

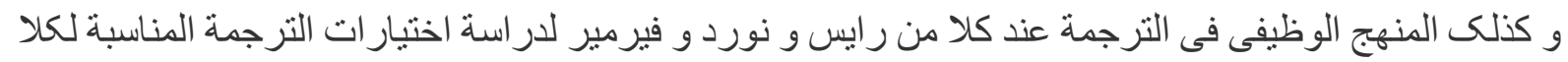

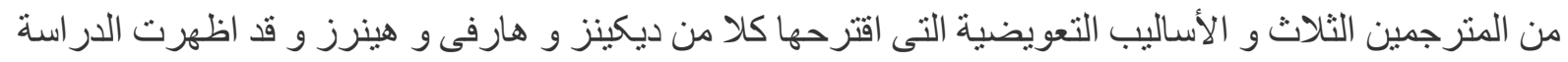

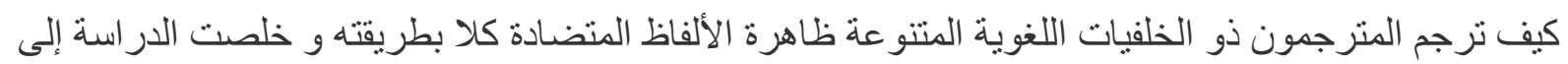

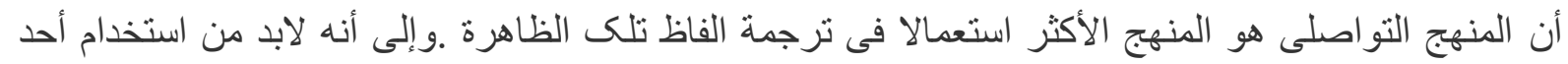
الأساليب التعويضية عند ترجمة تلك الألفاظ لتعويض المعنى الأخر المفقود فى الترجمة. 